\title{
WHAT DRIVES PERSISTENTLY HIGH INFLATIONARY PRESSURES IN VIETNAM? SOME EVIDENCE FROM THE NEW KEYNESIAN CURVE FRAMEWORK
}

\author{
Xuan-Hoa Nghiem*, and Seema Narayan** \\ * Faculty of International Economics, Foreign Trade University, Hanoi 100000, Vietnam. \\ Email: hoanx@ftu.edu.vn. \\ ** Corresponding author. Independent Researcher, Melbourne, Victoria, Australia. \\ Email: swdhar27@gmail.com
}

\begin{abstract}
In this study, we revisit the inflation process in Vietnam through the New Keynesian Phillips Curve (NKPC) model. We use monthly and quarterly data frequencies to track the forces driving inflationary pressures up to a quarter. Interest rate, an important determinant of inflation, is often found to give theoretically inconsistent result. Hence, we examine different interest rates, including, the central bank policy rate, lending interest rate and one-month interbank interest rates. Further, there is no unified approach to measuring the output gap - an important variable of the model - in the literature which may affect the results. Therefore, in this study, output gap is measured using two different approaches, namely, the linear trend model and the Hodrick-Prescott (HP) filter to see whether different measurement approaches matter for the signs and significance of this variable. Our key findings show that while the effects of interest rate vary by its type, measurement of output gap does not matter for the determination of inflation in Vietnam. What matters is whether the inflation model is quarterly or monthly. We explain the main determinants of inflation and provide some policy implications in the paper.
\end{abstract}

Keywords: Inflation; Interest rate; Exchange rate; Output gap.

JEL Classifications: E31; E52.

\author{
Article history: \\ Received : : May 19, 2021 \\ Revised : November 20, 2021 \\ Accepted : December 07, 2021 \\ Available online : December 31, 2021 \\ https://doi.org/10.21098/bemp.v24i4.1766
}




\section{INTRODUCTION}

Since the introduction of its Doi Moi (also known as Renovation) policy, the Vietnamese economy has registered a remarkable growth rate (Narayan and Nguyen, 2016). However, probably owing to both external (the Asian Financial Crisis-AFC in 1997, the Global Financial Crisis-GFC in 2008, the energy crisis in 2000s) and internal (the consequences of the Vietnam War, economic mismanagement) factors, the Vietnamese economy also suffered from several periods of double-digit inflation rate from late 1988 to early 1990, in the late 2007 to early 2009 and then from late 2010 to early 2012 (see Figure 1).

Figure 1.

\section{Inflation in Vietnam}

This figure displays the inflation in Vietnam.

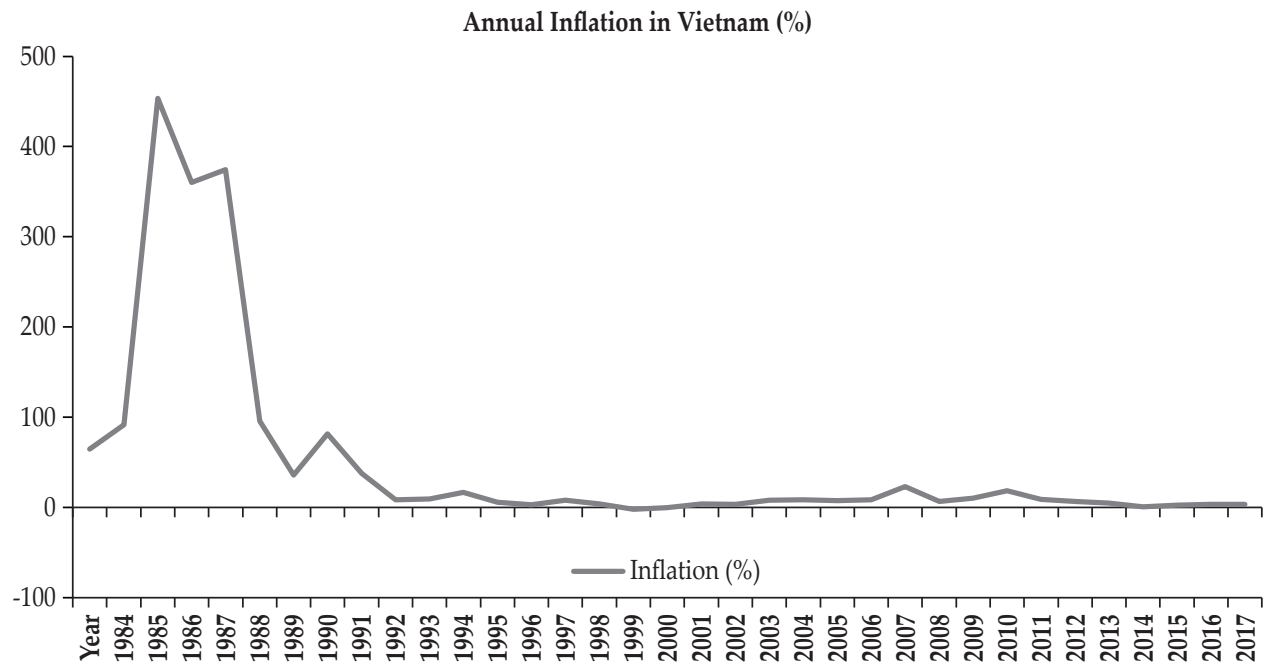

Source: World Bank's World Development Indicators (WDI)

As inflation has always been a major cause of concern in Vietnam ${ }^{1}$, this study investigates the inflation process under the New Keynesian Philips Curve (NKPC). Our contributions to the extant literature on inflation determination are as follows. First, we model inflation using different types of interest rate. While there are several similar studies, they only use interest rates at one or two maturity level (see Table 1 for a summary of the literature). Moreover, as an important determinant of inflation, interest rate is often found to give theoretically inconsistent result

1 At the end of each year, the Vietnamese government has to submit an annual draft plan of macroeconomic objectives of inflation and economic growth to be reached next year to the Vietnamese National Assembly for approval. A low inflation is also the focus of the Vietnamese government as affirmed by Dizioli and Schmittmann (2015). Bhattacharya (2014) also confirms that the Vietnamese economy suffered from high and volatile inflation since 2007. Nguyen and Nguyen (2010) argue that the bitter experiences with hyper-inflation in the 1980s and early 1990s as well as double-digit inflation in 2008 cause inflation inertia to be serious. 
(Podkaminer, 1998; Rabanal, 2003; Oomes and Ohnsorge, 2005; Ravenna and Walsh, 2006; Gaiotti and Secchi, 2006; Chowdhury et al., 2006; Tillman, 2009; Henzel et al., 2009; Kaufmann and Scharler, 2009; Ali and Anwar, 2013; Florio, 2018; Vo and Nguyen, 2017). Hence, we examine different interest rates, including, the central bank policy rate, the lending interest rate and the one-month interbank interest rates. Our findings show that interest rate type matters. Specifically, we find that while interest rates of all maturities have the same positive impact on inflation, their significance varies. At the quarterly models, the central bank policy rate, the lending rate and one-month interbank interest rates are significant. However, at the monthly models, only the lending interest rate is significant, suggesting that other types of interest rate have a delayed effect on inflation.

Second, we follow Lee (1995) and use two data frequencies, namely monthly and quarterly, in this paper to test for any instability of the inflation determination across frequencies. Lee (1995) is the only study on inflation that uses multiple data frequencies (annual and quarterly), and finds that the US Phillips curve is unstable across both time and frequency as annual and quarterly results are varied. ${ }^{2}$ Our findings show that inflation determination in the monthly and quarterly frequencies differ significantly. Specifically, we find that in the monthly models, the lending interest rate, the government budget deficit, the output gap (two different measures), leads and lags of inflation matter for the inflation determination in Vietnam and in the quarterly models, the central bank policy rate, the lending interest rate and the one-month interbank interest rates, leads and lags of inflation matter. Third, we notice that output gap, an important determinant of inflation is measured in several ways in the literature. It is unclear whether the relationship between inflation and output gap depends on the measure used. Hence, we take two approaches widely used in the literature to measure output gap, and examine the inflation models with each of two output gap measures. We show that output gap developed using the linear trend model and the HP filter produce consistent results - in all cases, we find that output gap has a negative and significant effect in the monthly models. Their effect on inflation is found to be insignificant in the quarterly models.

This paper is organized in the following manner. Section II summarizes the extant literature as well as specifies the empirical model while Section III explains the data and provides the preliminary analysis of the data. Section IV discusses the main empirical results, while Section V concludes the study.

\section{EMPIRICAL LITERATURE REVIEW AND MODEL SPECIFICATION}

The empirical literature on inflation is voluminous and diverse in terms of the countries investigated, the methods and variables selected. We summarize the empirical studies in Table 1 below.

\footnotetext{
2 The importance of data frequency has been confirmed in the finance literature (see Narayan et al., 2013; Narayan and Sharma, 2015; Narayan and Rehman, 2017, 2019). However, apart from Lee (1995), no attempt has been made to examine inflation model at different frequencies.
} 


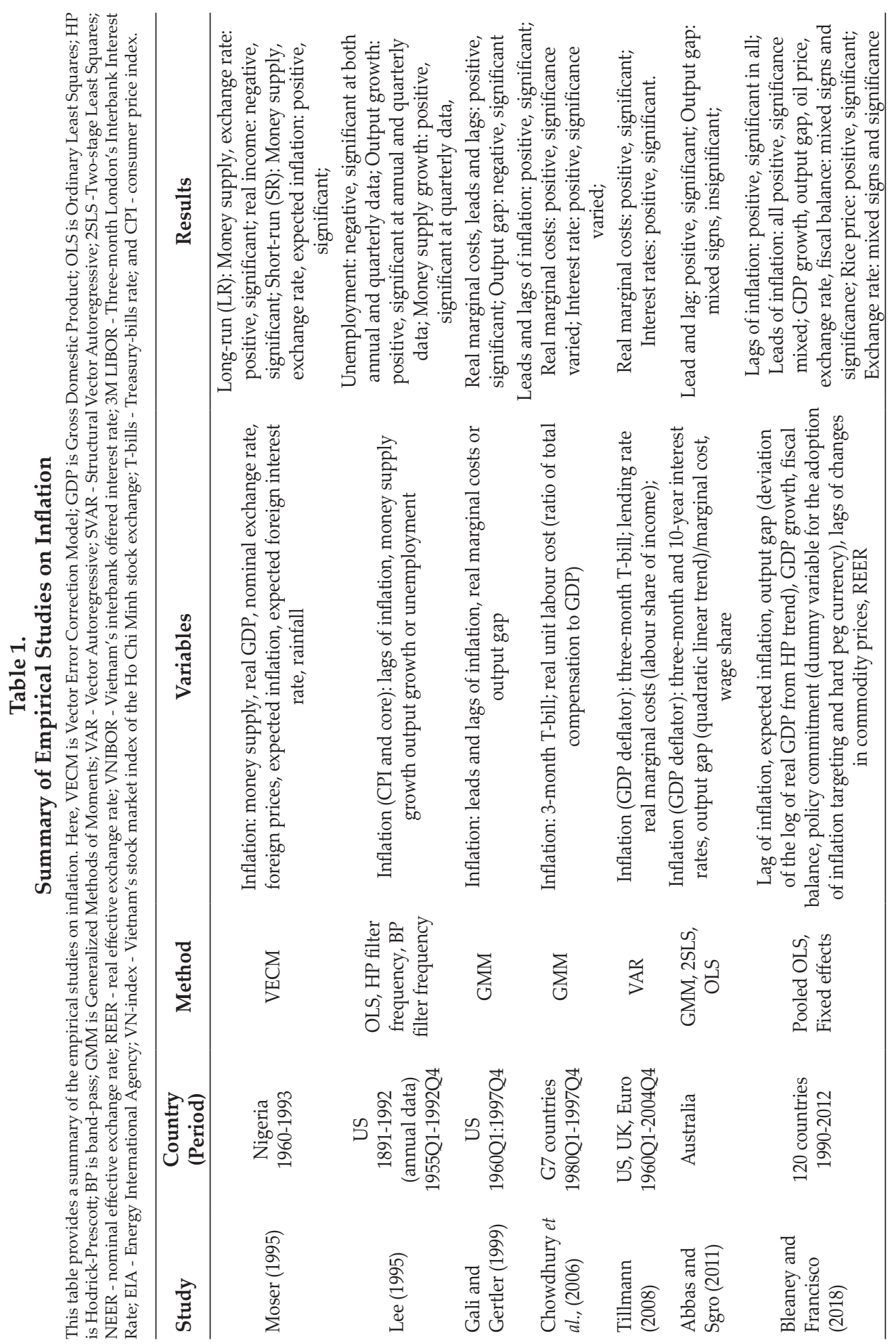




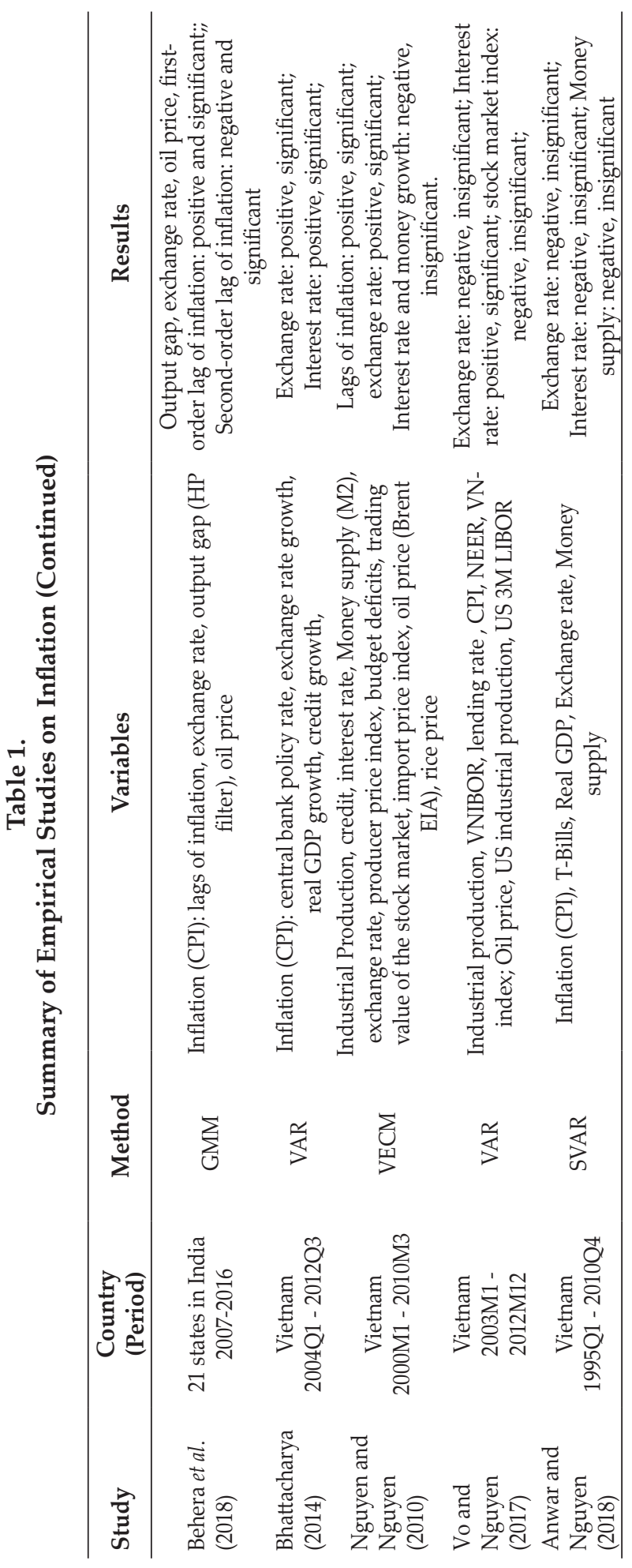


The determinants of inflation make up a popular subject and an enormous volume in the literature of macroeconomics. While underlying theories (such as the quantity theory of money) motivating the relationship between inflation and its determinants are well-established and provide a proper explanation for inflation determination, these theories only cover a simple and reduced-form model of inflation process while the NKPC framework can supply an in-depth understanding of the inflation process (Keen Meng, 2016). ${ }^{3}$

Following Gali and Gertler (1999), Chowdhury et al. (2006), Tillmann (2009), and Lanne and Luoto (2014), Behera et al. (2018) and Narayan et al. (2019), the hybrid open-economy version of the NKPC for Vietnam is specified as follows:

$$
\begin{aligned}
& \pi_{t}=\alpha_{0}+\alpha_{1} e_{t}+\alpha_{2} i_{t}+\alpha_{3} m_{t}+\alpha_{4} g b d_{t}+\alpha_{5} g a p_{t}+\sum_{i=1}^{t} \alpha_{6 i}\left(\pi_{t-i}\right)+ \\
& \sum_{i=1}^{t} \alpha_{7 i}\left(\pi_{t+i}\right)+\alpha_{8} i p i_{t}+\alpha_{9} \text { oil }_{t}+\alpha_{10} \text { rice }_{t}+\varepsilon_{t}
\end{aligned}
$$

where $\pi_{t}$ is inflation rate measured as year-on-year growth of CPI, $\pi_{t-i}$ is lag(s) of inflation, $\pi_{t+i}$ is lead(s) of inflation, $e_{t}$ is exchange rate (number of VND per 1 $\mathrm{USD}$ ), $i_{t}$ is the interest rate (one of the following: central bank policy rate, lending interest rate, one-month interbank interest rates) $m_{t}$ is money supply proxied by broad money $M 2, g b d_{t}$ is the ratio of government budget deficit over GDP, gap is the output gap (derived from the HP filter, linear trend model or quadratic trend model), ipi $_{\text {t }}$ is import price index, oil is the Brent oil price (USD per barrel), rice ${ }_{t}$ is the rice price (USD per metric ton), $\varepsilon_{t}$ is the error term and $\Delta$ is the first-difference operator. While the interest rate has an expected negative sign, the exchange rate, money supply, government budget deficit, output gap, import price index, oil price and rice price are expected to have positive signs.

While all other variables are relatively easily accessible (see Table 2 below), the variable, output gap, deserves some attention here. Defined as the difference between actual output and potential output, output gap usually occupies an essential role in the NKPC framework ${ }^{4}$. However, there is a variety of ways to derive this variable. Some scholars prefer the use of a linear trend model (Abbas and Sgro, 2011; Abbas et al., 2016; Bleaney and Francisco, 2018; Florio, 2018) or quadratic trend model (Abbas and Srgo, 2011; Lanne and Luoto, 2014) to derive the potential output and then compute the output gap. Others (Hahn, 2003; Ramakrishnan and Vamvakidis, 2002; Batini et al., 2005; Paul, 2009) make use of the HP filter to extract potential GDP and then calculate the output gap as the difference between actual and potential GDP. In order to see whether the impact of the output gap is dependent on how it is derived, this study employs two measures to calculate the output gap (HP filter and linear trend models).

3 For a detailed discussion of the quantity theory of money and its extensions, see Mankiw (2016) and Nghiem (2020).

4 Both Giordani (2004) and Florio (2018) argue that the output gap should be used instead of real GDP in an inflation model because the omission of the output gap is likely to lead to the price puzzle. 


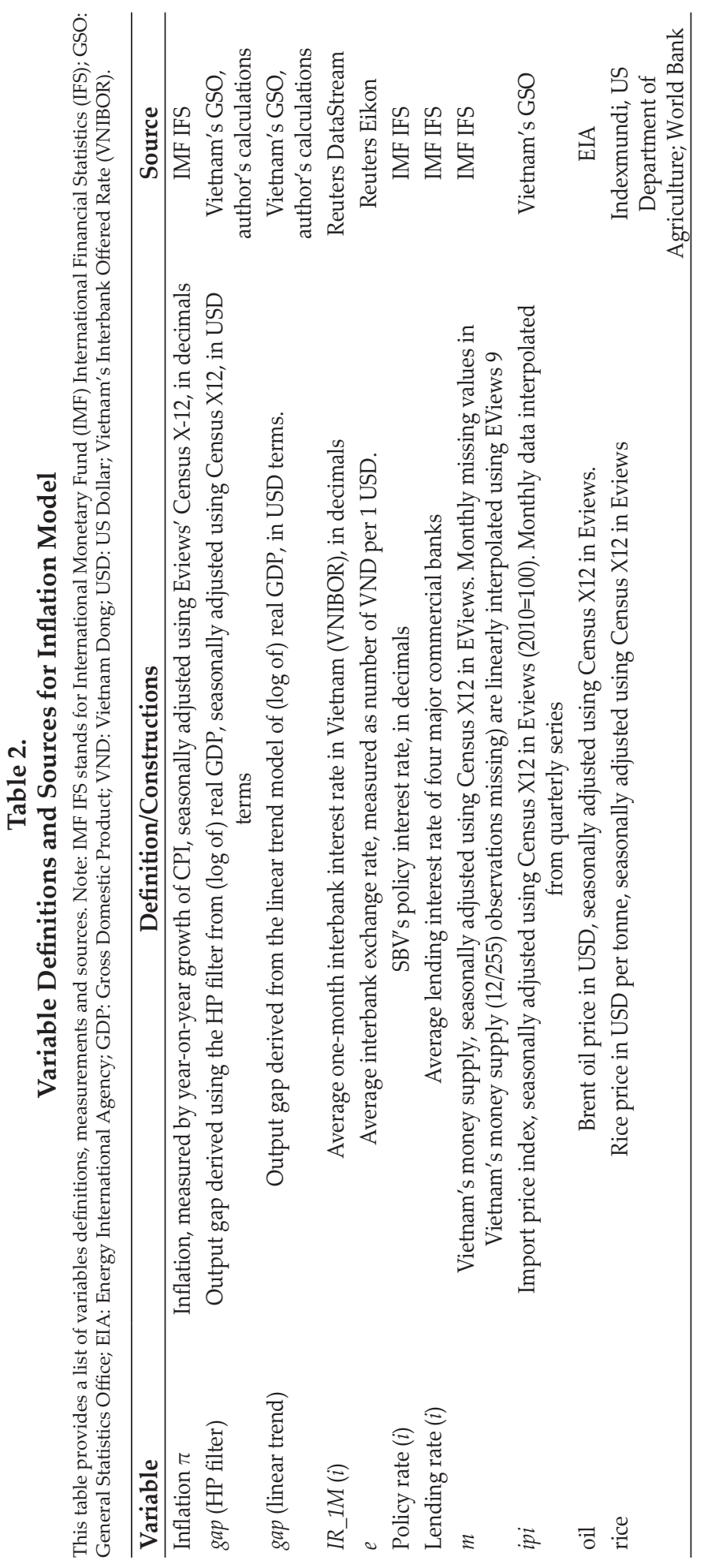




\section{DATA AND PRELIMINARY ANALYSIS}

Data are sourced from IMF's International Financial Statistics, Vietnam's General Statistics Office (GSO), Thomson Reuters Datastream, Energy International Agency and Indexmundi. Tables 3 and 4 present the descriptive statistics as well as results of the ADF and PP unit root tests of the variables used in the estimation at the quarterly and monthly frequencies, respectively.

According to the results, most variables are non-stationary at their level forms while becoming stationary at their first-difference forms. There are some cases where the ADF test and PP test give conflicting results (namely, the output gap derived from the HP filter, the central bank policy rate; the output gap derived from the HP filter,). However, to avoid the problem of spurious regression, all variables will enter the model in their first-difference form $\mathrm{s}^{56}$.

\section{EMPIRICAL RESULTS}

\section{A. Empirical Results}

Empirical estimations of the augmented NKPC are presented in Tables 5 to 7 . The optimal number of lead(s) and lag(s) is chosen using SIC.

5 We also measure the output gap using the quadratic linear trend model. However, results using this approach are very similar to those when the output gap derived from the HP filter and linear trend model. These results are available upon request.

6 Under the NKPC framework, the unemployment rate is also used instead of the output gap. However, results of the PP unit root test indicate that this variable is $\mathrm{I}(2)$ across both quarterly and monthly frequencies. Therefore, it is not used in the model. 


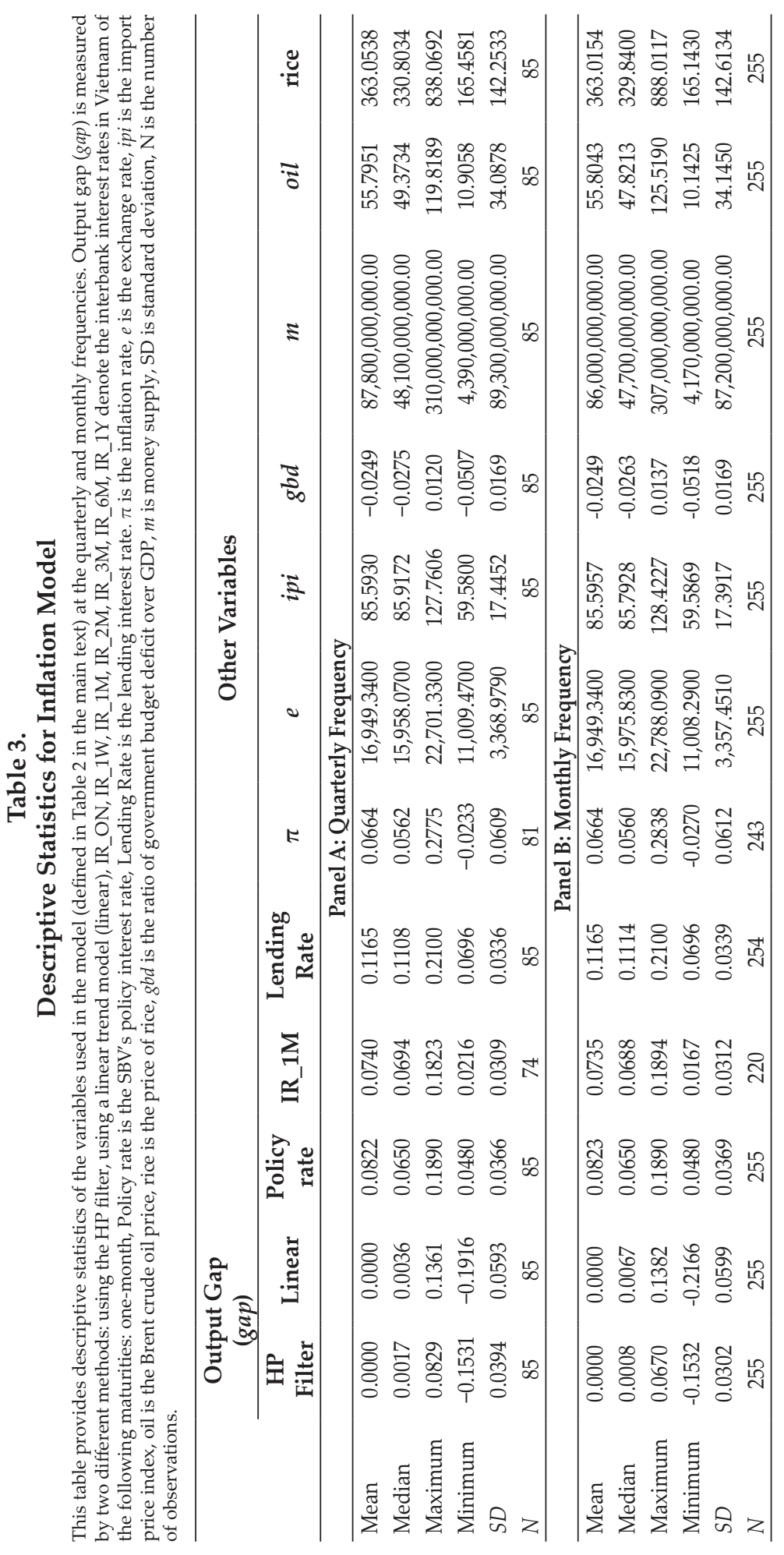




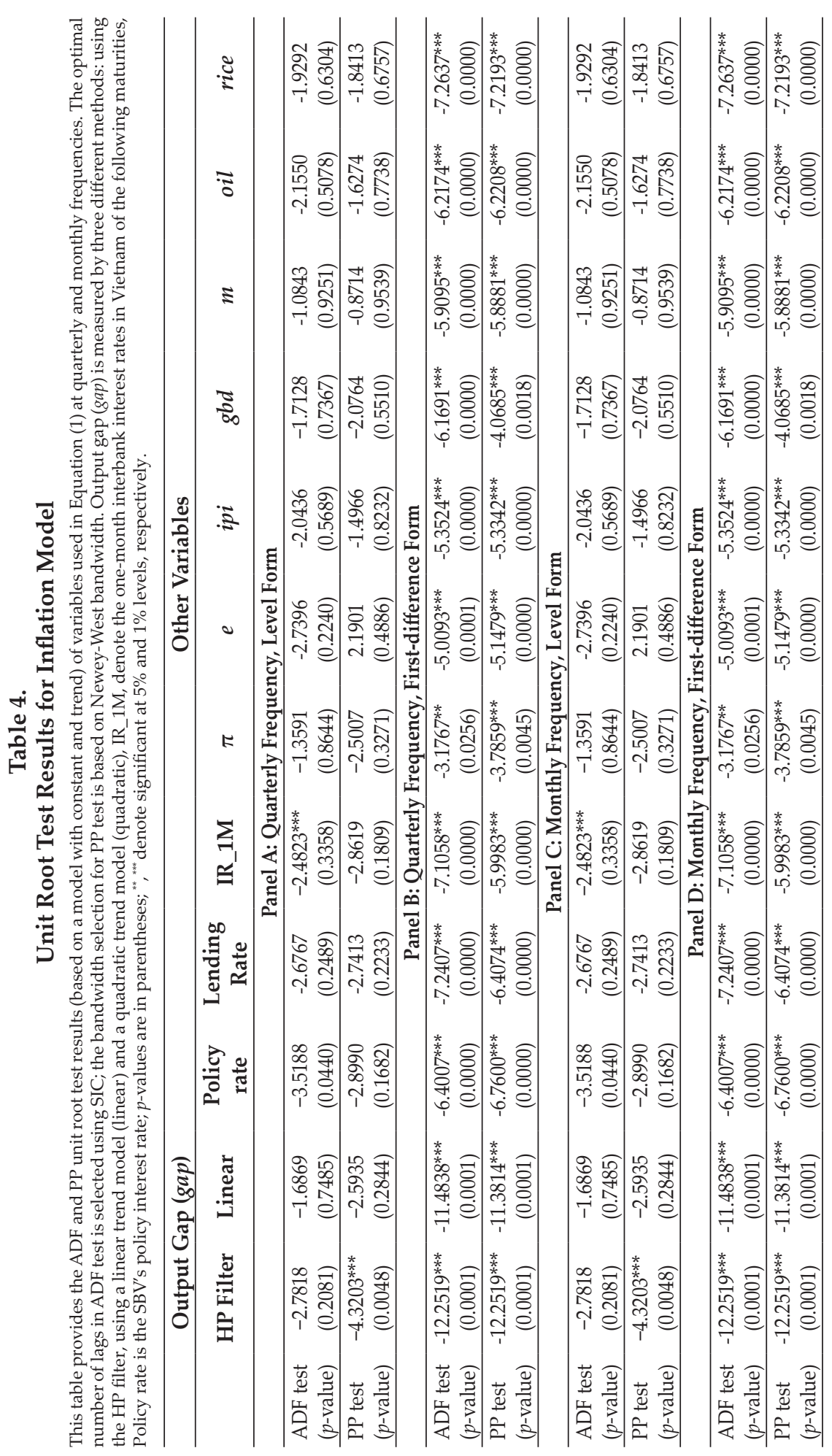


Table 5.

\section{Determinants of Inflation - Interest Rates is the Central Bank Policy Rate}

This table presents empirical analysis of inflation in Vietnam using equation (1) at quarterly and monthly frequencies where interest rate is the central bank policy rate. The first column contains list of variables which are defined as follows: the dependent variable $\pi_{t}$ is Vietnam's inflation rate (year-on-year growth of CPI); $c$ is the constant, $e_{t}$ is exchange rate (in log), $i_{t}$ is the central bank policy interest rate, $m_{t}$ is money supply (in log), $g b d_{t}$ is the ratio of government budget deficit over GDP, gap is the output gap (measured by HP filter or linear trend model), $\pi_{t-i}$ is lag $i^{\text {th }}$ of inflation, $\pi_{t+i}$ is lead $i^{\text {th }}$ of inflation, $i p i_{t}$ is import price index (in log), oil $t_{t}$ is the Brent oil price (USD per barrel, in log), rice $_{t}$ is the rice price (USD per metric ton, in $\log$ ), $\Delta$ is the first-difference operator. The $p$-values are in parentheses. $R n^{2}$ is the test of joint-significance of all variables in the model, $N$ is the number of observations, ${ }^{* *},{ }^{* * *}$ denote significant at $5 \%$ and $1 \%$ levels respectively. The last four columns (which are divided into two groups: quarterly frequency and monthly frequency) present results when the output gap is computed using HP filter or linear trend model. The optimal number of lead(s) and lag(s) is chosen using SIC.

\begin{tabular}{|c|c|c|c|c|}
\hline & \multicolumn{2}{|c|}{ Quarterly Frequency } & \multicolumn{2}{|c|}{ Monthly Frequency } \\
\hline & $\begin{array}{l}\text { Output gap } \\
\text { using HP } \\
\text { filter }\end{array}$ & $\begin{array}{c}\text { Output gap } \\
\text { using Linear } \\
\text { Trend }\end{array}$ & $\begin{array}{l}\text { Output gap using } \\
\text { HP filter }\end{array}$ & $\begin{array}{l}\text { Output gap using } \\
\text { Linear Trend }\end{array}$ \\
\hline$c$ & $\begin{array}{c}0.0037 \\
(0.3172)\end{array}$ & $\begin{array}{c}0.0038 \\
(0.2990)\end{array}$ & $\begin{array}{l}-0.0001 \\
(0.9029)\end{array}$ & $\begin{array}{c}0.0001 \\
(0.8275)\end{array}$ \\
\hline$\Delta e_{t}$ & $\begin{array}{l}-0.1677 \\
(0.2994)\end{array}$ & $\begin{array}{l}-0.1817 \\
(0.2642)\end{array}$ & $\begin{array}{l}-0.1287^{* *} \\
(0.0257)\end{array}$ & $\begin{array}{l}-0.1131 \\
(0.0538)\end{array}$ \\
\hline$\Delta i_{t}$ & $\begin{array}{l}0.5030^{* *} \\
(0.0118)\end{array}$ & $\begin{array}{l}0.4988^{* *} \\
(0.0120)\end{array}$ & $\begin{array}{c}0.0316 \\
(0.5913)\end{array}$ & $\begin{array}{c}0.0367 \\
(0.5343)\end{array}$ \\
\hline$\Delta m_{t}$ & $\begin{array}{l}-0.0328 \\
(0.5274)\end{array}$ & $\begin{array}{l}-0.0331 \\
(0.5210)\end{array}$ & $\begin{array}{c}0.0052 \\
(0.8260)\end{array}$ & $\begin{array}{l}-0.0015 \\
(0.9506)\end{array}$ \\
\hline$\Delta g b d_{t}$ & $\begin{array}{l}0.9349^{* *} \\
(0.0489)\end{array}$ & $\begin{array}{l}0.9416^{* *} \\
(0.0477)\end{array}$ & $\begin{array}{l}0.5806^{* *} \\
(0.0237)\end{array}$ & $\begin{array}{c}0.4977 \\
(0.0546)\end{array}$ \\
\hline$\Delta g a p_{t}$ & $\begin{array}{l}-0.0846 \\
(0.1387)\end{array}$ & $\begin{array}{l}-0.0885 \\
(0.1136)\end{array}$ & $\begin{array}{l}-0.1015^{* * *+} \\
(0.0001)\end{array}$ & $\begin{array}{l}-0.0950^{*+* *+} \\
(0.0003)\end{array}$ \\
\hline$\Delta \pi_{t-1}$ & $\begin{array}{l}0.3619^{m+x} \\
(0.0000)\end{array}$ & $\begin{array}{l}0.3595^{n+4} \\
(0.0000)\end{array}$ & $\begin{array}{l}0.3788^{*} \\
(0.0000)\end{array}$ & $\begin{array}{l}0.4059^{2+x} \\
(0.0000)\end{array}$ \\
\hline$\Delta \pi_{t+1}$ & $\begin{array}{l}0.2528^{* * *} \\
(0.0089)\end{array}$ & $\begin{array}{l}0.2473^{* *} \\
(0.0103)\end{array}$ & $\begin{array}{l}0.3533^{* * x} \\
(0.0000)\end{array}$ & $\begin{array}{l}0.3663^{3 * x} \\
(0.0000)\end{array}$ \\
\hline$\Delta \pi_{t-2}$ & & & $\begin{array}{l}-0.0996^{* *} \\
(0.0450)\end{array}$ & $\begin{array}{l}-0.1263^{*+} \\
(0.0114)\end{array}$ \\
\hline$\Delta \pi_{t+2}$ & & & $\begin{array}{l}-0.0269 \\
(0.5986)\end{array}$ & $\begin{array}{l}-0.0096 \\
(0.8520)\end{array}$ \\
\hline$\Delta \pi_{t-3}$ & & & $\begin{array}{l}0.1219^{* * * *} \\
(0.0067)\end{array}$ & $\begin{array}{l}0.1240^{* * * *} \\
(0.0060)\end{array}$ \\
\hline$\Delta \pi_{t+3}$ & & & $\begin{array}{c}0.0694 \\
(0.1363)\end{array}$ & $\begin{array}{c}0.0315 \\
(0.5009)\end{array}$ \\
\hline$\Delta i p i_{t}$ & $\begin{array}{c}0.0668 \\
(0.2821)\end{array}$ & $\begin{array}{c}0.0691 \\
(0.2632)\end{array}$ & $\begin{array}{c}0.0227 \\
(0.4953)\end{array}$ & $\begin{array}{c}0.0219 \\
(0.5110)\end{array}$ \\
\hline$\Delta o i l_{t}$ & $\begin{array}{c}0.0033 \\
(0.7977)\end{array}$ & $\begin{array}{c}0.0036 \\
(0.7763)\end{array}$ & $\begin{array}{l}-0.0012 \\
(0.7793)\end{array}$ & $\begin{array}{l}-0.0024 \\
(0.5579)\end{array}$ \\
\hline$\Delta_{\text {rice }}{ }_{t}$ & $\begin{array}{c}0.0283 \\
(0.1171)\end{array}$ & $\begin{array}{c}0.0291 \\
(0.1046)\end{array}$ & $\begin{array}{c}0.0117 \\
(0.1069)\end{array}$ & $\begin{array}{l}0.0291^{\text {wax }} \\
(0.0001)\end{array}$ \\
\hline $\operatorname{Adj} R^{2}$ & 0.4852 & 0.4773 & 0.3414 & 0.3413 \\
\hline $\begin{array}{l}R n^{2} \\
\text { (prob) }\end{array}$ & $\begin{array}{c}214.5489^{*+*+*} \\
(0.0000)\end{array}$ & $\begin{array}{l}215.0155^{* * * *} \\
(0.0000)\end{array}$ & $\begin{array}{c}599.4179^{*+*} \\
(0.0000)\end{array}$ & $\begin{array}{c}648.4779^{*+1+} \\
(0.0000)\end{array}$ \\
\hline$N$ & 78 & 78 & 234 & 234 \\
\hline
\end{tabular}


Table 6.

Determinants of Inflation - Interest Rate is the Lending Rate

This table presents empirical analysis of inflation in Vietnam using equation (1) at quarterly and monthly frequencies where interest rate is the lending interest rate. The first column contains list of variables which are defined as follows: the dependent variable $\pi_{t}$ is Vietnam's inflation rate (year-on-year growth of CPI); $c$ is the constant, $e_{t}$ is exchange rate (in $\log$ ), $i_{t}$ is the central bank policy interest rate, $m_{t}$ is money supply (in log), $g b d_{t}$ is the ratio of government budget deficit over GDP, gap $p_{t}$ is the output gap (measured by HP filter or linear trend model), $\pi_{t-i}$ is lag $i^{\text {th }}$ of inflation, $\pi_{t+i}$ is lead $i^{\text {th }}$ of inflation, $i p i_{t}$ is import price index (in log), oil is the Brent oil price (USD per barrel, in log), rice, is the rice price (USD per metric ton, in log), $\Delta$ is the first-difference operator. The $p$-values are in parentheses. $R n^{2}$ is the test of joint-significance of all variables in the model, $N$ is the number of observations, ${ }^{* * * *}$ denote significant at $5 \%$ and $1 \%$ levels respectively. The last four columns (which are divided into two groups: quarterly frequency and monthly frequency) present results when the output gap is computed using HP filter or linear trend model. The optimal number of lead(s) and lag(s) is chosen using SIC.

\begin{tabular}{|c|c|c|c|c|}
\hline & \multicolumn{2}{|c|}{ Quarterly Frequency } & \multicolumn{2}{|c|}{ Monthly Frequency } \\
\hline & $\begin{array}{l}\text { Output gap } \\
\text { using HP filter }\end{array}$ & $\begin{array}{c}\text { Output gap } \\
\text { using Linear } \\
\text { Trend } \\
\end{array}$ & $\begin{array}{c}\text { Output gap using } \\
\text { HP filter }\end{array}$ & $\begin{array}{l}\text { Output gap using } \\
\text { Linear Trend }\end{array}$ \\
\hline 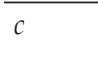 & $\begin{array}{c}0.0058 \\
(0.0813)\end{array}$ & $\begin{array}{c}0.0059 \\
(0.0740)\end{array}$ & $\begin{array}{c}0.0002 \\
(0.7351)\end{array}$ & $\begin{array}{c}0.0002 \\
(0.7654)\end{array}$ \\
\hline$\Delta e_{t}$ & $\begin{array}{l}-0.1673 \\
(0.2729)\end{array}$ & $\begin{array}{l}-0.1826 \\
(0.2307)\end{array}$ & $\begin{array}{c}-0.1503^{* * *} \\
(0.0071)\end{array}$ & $\begin{array}{l}-0.0898 \\
(0.1202)\end{array}$ \\
\hline$\Delta i_{t}$ & $\begin{array}{l}0.4745^{* * 4} \\
(0.0049)\end{array}$ & $\begin{array}{l}0.4749^{+3+4} \\
(0.0043)\end{array}$ & $\begin{array}{c}0.1044 \\
(0.0926)\end{array}$ & $\begin{array}{l}0.1270^{* * *} \\
(0.0433)\end{array}$ \\
\hline$\Delta m_{t}$ & $\begin{array}{l}-0.0649 \\
(0.1517)\end{array}$ & $\begin{array}{l}-0.0644 \\
(0.1491)\end{array}$ & $\begin{array}{c}0.0008 \\
(0.9732)\end{array}$ & $\begin{array}{l}-0.0005 \\
(0.9840)\end{array}$ \\
\hline$\Delta g b d_{t}$ & $\begin{array}{c}0.4675 \\
(0.2931)\end{array}$ & $\begin{array}{c}0.4679 \\
(0.2892)\end{array}$ & $\begin{array}{l}0.7331^{\text {w* }} \\
(0.0019)\end{array}$ & $\begin{array}{l}0.5882^{*} \\
(0.0179)\end{array}$ \\
\hline$\Delta g a p_{t}$ & $\begin{array}{l}-0.0721 \\
(0.1769)\end{array}$ & $\begin{array}{l}-0.0763 \\
(0.1413)\end{array}$ & $\begin{array}{l}-0.0880^{*+1+4} \\
(0.0003)\end{array}$ & $\begin{array}{c}-0.0822^{*+1+*} \\
(0.0008)\end{array}$ \\
\hline$\Delta \pi_{t-1}$ & $\begin{array}{l}0.3398^{* *+*} \\
(0.0000)\end{array}$ & $\begin{array}{l}0.3366^{*+1+} \\
(0.0000)\end{array}$ & $\begin{array}{l}0.3596^{* * *} \\
(0.0000)\end{array}$ & $\begin{array}{l}0.4125^{* * *} \\
(0.0000)\end{array}$ \\
\hline$\Delta \pi_{t+1}$ & $\begin{array}{l}0.2313^{* *} \\
(0.0114)\end{array}$ & $\begin{array}{l}0.2259^{* * *} \\
(0.0125)\end{array}$ & $\begin{array}{l}0.3311^{* * *} \\
(0.0000)\end{array}$ & $\begin{array}{l}0.3172^{n+0 \times} \\
(0.0000)\end{array}$ \\
\hline$\Delta \pi_{t-2}$ & & & & $\begin{array}{l}-0.0676 \\
(0.1240)\end{array}$ \\
\hline$\Delta \pi_{t+2}$ & & & & $\begin{array}{c}0.0108 \\
(0.8197)\end{array}$ \\
\hline$\Delta i p i_{t}$ & $\begin{array}{c}0.1088 \\
(0.0533)\end{array}$ & $\begin{array}{l}0.1096^{* * *} \\
(0.0485)\end{array}$ & $\begin{array}{c}0.0532 \\
(0.0951)\end{array}$ & $\begin{array}{c}0.0436 \\
(0.1856)\end{array}$ \\
\hline$\Delta o i l_{t}$ & $\begin{array}{l}-0.0063 \\
(0.6292)\end{array}$ & $\begin{array}{l}-0.0060 \\
(0.6398)\end{array}$ & $\begin{array}{l}-0.0035 \\
(0.4105)\end{array}$ & $\begin{array}{l}-0.0035 \\
(0.4090)\end{array}$ \\
\hline srice $_{t}$ & $\begin{array}{c}0.0258 \\
(0.1231)\end{array}$ & $\begin{array}{c}0.0269 \\
(0.1028)\end{array}$ & $\begin{array}{c}0.0118 \\
(0.0960)\end{array}$ & $\begin{array}{l}0.0196^{* * t} \\
(0.0058)\end{array}$ \\
\hline Adj $R^{2}$ & 0.4334 & 0.4264 & 0.3532 & 0.3408 \\
\hline $\begin{array}{l}R n^{2} \\
\text { (prob) }\end{array}$ & $\begin{array}{c}213.4581^{* * * * x} \\
(0.0000)\end{array}$ & $\begin{array}{c}217.2886^{* * * *} \\
(0.0000)\end{array}$ & $\begin{array}{c}574.4409^{* * * *+} \\
(0.0000)\end{array}$ & $\begin{array}{c}573.3105^{* * *} \\
(0.0000)\end{array}$ \\
\hline$N$ & 78 & 78 & 238 & 236 \\
\hline
\end{tabular}


Table 7.

\section{Determinants of Inflation - Interest Rate is the One-month Interbank Rate}

This table presents empirical analysis of inflation in Vietnam using equation (1) at quarterly frequency where interest rate is the one-month interbank interest rate. The first column contains list of variables which are defined as follows: the dependent variable $\pi_{t}$ is Vietnam's inflation rate (year-on-year growth of CPI); $c$ is the constant, $e_{t}$ is exchange rate (in log), $i_{t}$ is the central bank policy interest rate, $m_{t}$ is money supply (in log), $g b d_{t}$ is the ratio of government budget deficit over GDP, gap $p_{t}$ is the output gap (measured by HP filter or linear trend model), $\pi_{t-i}$ is lag $i^{\text {th }}$ of inflation, $\pi_{t+i}$ is lead $i^{\text {th }}$ of inflation, ipi is import price index (in log), oil t is the Brent oil price (USD per barrel, in log), rice, is the rice price (USD per metric ton, in log), $\Delta$ is the first-difference operator. The $p$-values are in parentheses. $R n^{2}$ is the test of joint-significance of all variables in the model, $N$ is the number of observations, ${ }^{* * *}$, denote significant at $5 \%$ and $1 \%$ levels respectively. The last four columns (which are divided into two groups: quarterly frequency and monthly frequency) present results when the output gap is computed using HP filter or linear trend model. The optimal number of lead(s) and lag(s) is chosen using SIC.

\begin{tabular}{|c|c|c|c|c|}
\hline & \multicolumn{2}{|c|}{ Quarterly Frequency } & \multicolumn{2}{|c|}{ Monthly Frequency } \\
\hline & $\begin{array}{c}\text { Output gap } \\
\text { using HP } \\
\text { filter }\end{array}$ & $\begin{array}{c}\text { Output gap } \\
\text { using Linear } \\
\text { Trend } \\
\end{array}$ & $\begin{array}{l}\text { Output gap using } \\
\text { HP filter }\end{array}$ & $\begin{array}{l}\text { Output gap using } \\
\text { Linear Trend }\end{array}$ \\
\hline$c$ & $\begin{array}{c}0.0014 \\
(0.6589)\end{array}$ & $\begin{array}{c}0.0014 \\
(0.6458)\end{array}$ & $\begin{array}{c}0.0000 \\
(0.9849)\end{array}$ & $\begin{array}{c}0.0000 \\
(0.9500)\end{array}$ \\
\hline$\Delta e_{t}$ & $\begin{array}{l}-0.1113 \\
(0.5041)\end{array}$ & $\begin{array}{l}-0.1204 \\
(0.4697)\end{array}$ & $\begin{array}{l}-0.2061^{* *+*} \\
(0.0028)\end{array}$ & $\begin{array}{l}-0.2123^{* * *+} \\
(0.0024)\end{array}$ \\
\hline$\Delta i_{t}$ & $\begin{array}{l}0.5158^{*} \\
(0.0000)\end{array}$ & $\begin{array}{l}0.5141^{* * x+} \\
(0.0000)\end{array}$ & $\begin{array}{c}0.0473 \\
(0.3388)\end{array}$ & $\begin{array}{c}0.0466 \\
(0.3481)\end{array}$ \\
\hline$\Delta m_{t}$ & $\begin{array}{l}-0.0035 \\
(0.9361)\end{array}$ & $\begin{array}{c}-0.0031 \\
(0.9431)\end{array}$ & $\begin{array}{c}0.0015 \\
(0.9495)\end{array}$ & $\begin{array}{c}0.0011 \\
(0.9639)\end{array}$ \\
\hline$\Delta g b d_{t}$ & $\begin{array}{c}0.4346 \\
(0.3010)\end{array}$ & $\begin{array}{c}0.4616 \\
(0.2740)\end{array}$ & $\begin{array}{l}0.6333^{* * *} \\
(0.0209)\end{array}$ & $\begin{array}{l}0.6193^{* * *} \\
(0.0255)\end{array}$ \\
\hline$\Delta g a p_{t}$ & $\begin{array}{l}-0.0621 \\
(0.2105)\end{array}$ & $\begin{array}{l}-0.0654 \\
(0.1801)\end{array}$ & $\begin{array}{l}-0.0988^{*+*+} \\
(0.0003)\end{array}$ & $\begin{array}{l}-0.0907^{*+0+} \\
(0.0009)\end{array}$ \\
\hline$\Delta \pi_{t-1}$ & $\begin{array}{l}0.4148^{*+4+} \\
(0.0000)\end{array}$ & $\begin{array}{l}0.4148^{* * x+4} \\
(0.0000)\end{array}$ & $\begin{array}{l}0.3009^{*+*} \\
(0.0000)\end{array}$ & $\begin{array}{l}0.3010^{*+1+4} \\
(0.0000)\end{array}$ \\
\hline$\Delta \pi_{t+1}$ & $\begin{array}{l}0.2813^{*+*+} \\
(0.0007)\end{array}$ & $\begin{array}{l}0.2777^{* * x+} \\
(0.0008)\end{array}$ & $\begin{array}{l}0.3588^{+40+4} \\
(0.0000)\end{array}$ & $\begin{array}{l}0.3577^{n+4 x} \\
(0.0000)\end{array}$ \\
\hline$\Delta \pi_{t-2}$ & & & $\begin{array}{l}-0.0303 \\
(0.5565)\end{array}$ & $\begin{array}{l}-0.0313 \\
(0.5469)\end{array}$ \\
\hline$\Delta \pi_{t+2}$ & & & $\begin{array}{c}0.0048 \\
(0.9272)\end{array}$ & $\begin{array}{c}0.0070 \\
(0.8948)\end{array}$ \\
\hline$\Delta \pi_{t-3}$ & & & $\begin{array}{l}0.1438^{+n+4} \\
(0.0022)\end{array}$ & $\begin{array}{l}0.1441^{*+*} \\
(0.0023)\end{array}$ \\
\hline$\Delta \pi_{t+3}$ & & & $\begin{array}{c}0.0503 \\
(0.3026)\end{array}$ & $\begin{array}{c}0.0464 \\
(0.3449)\end{array}$ \\
\hline$\Delta i p i_{t}$ & $\begin{array}{c}0.0199 \\
(0.7078)\end{array}$ & $\begin{array}{c}0.0207 \\
(0.6960)\end{array}$ & $\begin{array}{c}0.0345 \\
(0.3131)\end{array}$ & $\begin{array}{c}0.0357 \\
(0.2993)\end{array}$ \\
\hline$\Delta o i l_{t}$ & $\begin{array}{c}0.0000 \\
(0.9996)\end{array}$ & $\begin{array}{c}0.0002 \\
(0.9868)\end{array}$ & $\begin{array}{l}-0.0034 \\
(0.4170)\end{array}$ & $\begin{array}{l}-0.0032 \\
(0.4399)\end{array}$ \\
\hline srice $_{t}$ & $\begin{array}{c}0.0194 \\
(0.2043)\end{array}$ & $\begin{array}{c}0.0197 \\
(0.1966)\end{array}$ & $\begin{array}{c}0.0046 \\
(0.5128)\end{array}$ & $\begin{array}{c}0.0048 \\
(0.4957)\end{array}$ \\
\hline Adj $R^{2}$ & 0.5016 & 0.5010 & 0.3699 & 0.3689 \\
\hline $\begin{array}{l}R n^{2} \\
\text { (prob) }\end{array}$ & $\begin{array}{c}290.7887^{*+*} \\
(0.0000)\end{array}$ & $\begin{array}{c}293.4137^{* * *} \\
(0.0000)\end{array}$ & $\begin{array}{c}635.0096^{*+*} \\
(0.0000)\end{array}$ & $\begin{array}{c}622.1622^{*+*} \\
(0.0000)\end{array}$ \\
\hline$N$ & 72 & 72 & 216 & 216 \\
\hline
\end{tabular}




\section{B. Discussion of Results}

First, results in Tables 5 to 7 show that both the lead(s) and lag(s) of inflation are significant with quite consistent effects across both frequencies, implying that economic agents in Vietnam are both forward- and backward-looking. The significance of lead(s) and lag(s) of inflation also indicates that inflation is probably highly persistent in Vietnam, signaling that it could be difficult for the SBV to contain inflation.

Second, in contrast to the (highly) significant role of both lead(s) and lag(s) of inflation, the import price index, oil price and rice price are all insignificant across both frequencies.

The next variable grabbing special attention is the interest rate. In this study, there are several types of interest rates used: namely, the central bank policy rate, the lending interest rate and the one-month interbank interest rates. ${ }^{7}$ The results are quite consistent across maturities: at the quarterly frequency, almost all types of interest rates are significant. However, all of these rates have positive impact on inflation - which is inconsistent with theory. Although this result is in contrast to conventional theories, it is not uncommon in the literature and can be attributed to several reasons.

The first reason is that higher interest rates could be considered as a reference point for higher inflation expectations. McKinnon (1993) argues that when interest rates become higher, agents are likely to use the current high interest rates as a signal for higher expected inflation. Furthermore, Narayan et al. (2019) state that when agents are backward-looking, they tend to use past inflation to form inflation expectations. As a result, if a country already suffered high inflation and employed higher interest rates to contain inflation in the past, raising the present interest rates may be seen as the signal that inflation is likely to rise and therefore, fueling inflation rather than containing it.

Podkaminer (1998) puts forward that when interest rates rise, it will become more costly for firms to maintain their inventories, thus making the so-called excess market supply disappear which in turn, grant retailers a quasi-monopoly power to charge consumers with higher prices even when there is excessive production capacity. Another reason, according to Elliott (1962) and Ratchford (1973), is that higher interest rates may cause housing prices and durable prices to rise (direct effects) as well as make producers scale back their production or charge higher prices (indirect effects), thus pushing up inflation.

From a different perspective, Linnemann (2005) opines that under the presence of distorted income taxes, higher interest rates may have contradictory effects on prices. On the one hand, in the conventional demand channel, higher nominal interest rates may lead to higher real interest rates (due to sticky prices) which in turn, bring down consumption and lower prices. On the other hand, higher interest rates also imply greater debt burdens in the future. Heavier debt burden and repayments, through the effects of intertemporal substitutions, may lead to lowered labor supply and higher wages and prices.

\footnotetext{
As a robustness check, models using other remaining types of interest rates including: the deposit rate, the overnight, one-week, two-month, three-month, six-month, one-year interbank interest rates are also estimated. Generally, the results are the same, further strengthening the unexpected effects of interest rates on inflation, regardless of the types of interest rates used. These results will be available upon request.
} 
Also related to debt, Ali and Anwar (2013) propose another explanation for the positive effect of interest rate on inflation: the higher the level of public debt in a country is, the more likely that country will engage in debt monetization which in turn, may destroy monetary policy credibility and bring about undesirable consequences.

Last, but not least, for economies in transition (such as Vietnam), higher interest rates may fuel inflation rather than contain it. In these economies, monetary authorities usually decide and adjust their policy interest rates based on inflation dynamics, so interest rates have to "chase" inflation and higher interest rates are associated with higher inflation (Rother, 2000; Pelipas, 2006).

In the literature, the positive effects of higher interest rates on inflation are also known as the cost-channel of monetary policy. This channel has been confirmed by various authors (see Table 1 in Section III).

Regarding the case of Vietnam, the existence of the cost-channel has been confirmed in previous empirical studies. While Pham (2016) and Tran (2018) both document the positive impact of central bank policy rate on inflation, Vo and Nguyen (2017) record this impact using overnight interbank interest rate. Therefore, the positive effect of interest rates on inflation in this study further corroborate findings of previous studies and strengthen the existence of the costchannel of monetary policy in Vietnam.

However, when it comes to monthly frequency, the interest rate variable becomes insignificant, regardless of the type of interest rates used. In other words, the cost-channel of monetary policy in Vietnam is present at the quarterly frequency while it becomes negligible at the monthly level.

Similar to the interest rate, the exchange rate also has unexpected effects on inflation in Vietnam. Theoretically, the exchange rate variable should have positive sign as exchange rate devaluations/depreciations may put upward pressures on inflation. However, for Vietnam, this variable has a negative sign (insignificant at quarterly and significant at monthly levels), indicating that an appreciation of the exchange rate (rather than a depreciation) will cause inflation to rise.

At first glance, this effect may appear counter-intuitive. However, this phenomenon is not uncommon in the literature. Adu and Marbuah (2011) document this effect for Ghana while Nguyen (2015) as well as Anwar and Nguyen (2018) both confirm the upward pressures of exchange rate appreciation on prices and inflation. Similarly, Kandil and Morsy (2009) also find this effect for Oman and reason that the positive effects of exchange rate appreciation on inflation can be attributed to the so-called wealth effect: exchange rate appreciation also leads to higher purchasing power of domestic savings which in turn, causes people to spend more and therefore increases inflation. In terms of data frequency, this variable is insignificant across both frequencies.

The next variable is money supply. Theoretically, this variable should have positive sign as higher money supply will lead to higher inflation. However, in this study, money supply is insignificant across both frequencies and it has negative sign in the majority of cases at the quarterly frequency and has mixed signs (both positive and negative) at the monthly level. Although this effect is in contrast with theory, it is not uncommon in the literature. Anwar and Nguyen (2018) also find that the price level initially decreases before it increases in response to higher money supply in Vietnam (the impact is also insignificant). 
In addition to findings by Anwar and Nguyen (2018), we propose another explanation for the inconsistent effect of money supply on inflation: the (in) appropriateness of the measurement of money supply. Given the ever-higher level of financial innovation and liberalization, the current measurement of money supply as simple sum of monetary aggregates may no longer be appropriate. Empirical studies point out that the so-called Divisia monetary index (Divisia index) computed as a weighted average of the monetary components (where the weights sum to unity and are assigned to each component based on their features) - has superior performance in modelling the relationship with other macroeconomic variables (inflation, output, exchange rate). Therefore, the unexpected effect of money supply on inflation in Vietnam also draws the attention of relevant authorities to the computation of the Divisia index. In fact, the superiority of the Divisia index over their simple sum counterpart is confirmed by numerous researchers (Rotemberg et al.,1995; Schunk, 2001; Darrat et al., 2005; Dahalan et al., 2005; Drake and Fleissig, 2008; Binner et al., 2009; Serletis and Rahman, 2013; Florackis et al., 2014; Belongia and Ireland, 2015, 2019). The last reason, proposed by Su et al. (2016), states that when the central bank adopts a discretionary approach to monetary policy with a view to achieving both price stability and economic growth, it has to applies various monetary policy tools to regulate the supply of credit and money. Therefore price movement and money supply may move in opposite directions rather than the same direction as directed by the quantity theory of money.

Another important determinant of inflation, namely, the government budget deficit, is significant and has theoretically correct sign of positive across both frequencies. This finding is in consistent with findings by Dhakal et al. (1994); Jalil et al. (2014) and Adu and Marbuah (2011). At the quarterly frequency, this variable is insignificant while it becomes highly significant at the month level, probably suggesting that its effect is delayed similar to the case of the exchange rate mentioned above.

Output gap is insignificant at the quarterly and significant at the monthly levels, further confirming the delayed effects of variables and strengthening the hypothesis that the frequency of data does matter for the significance of variables. However, this variable has a consistent negative sign across both frequencies, no matter how it is derived (whether using the linear trend model or the HP filter). While the negative sign might seem counter-intuitive at first, this effect is not uncommon in the literature and can be attributed to several factors.

The first reason, according to Nugent and Glezakos (1982), is due to countrylevel differences. They argue that less developed countries, especially those whose the agriculture sector is important, are likely to have an upward-sloping traditional Phillips curve, implying that employment can have positive impact on inflation. Nugent and Glezakos (1982) state that this phenomenon is a mirror reflecting the stark differences in institutional quality between developed and least developed countries.

Another explanation for the negative sign of the output gap is proposed by Gali and Gertler (1999) as well as Abbas et al. (2016) for different specifications of the NKPC. They posit that the marginal costs constitute a better proxy for economic activities than the output gap does. Their empirical evidence also lends 
support to the use of marginal costs rather than the output gap in an NKPC model

In the empirical literature, the inconsistent and negative sign of the output gap has also been recorded for various countries. For example, Ramakrishnan and Vamvakidis (2002) (using quarterly data from 1980Q1-2000Q4) or Wimanda et al. (2011) (using monthly data from 1980M1 to 2008M12) all document the negative impact of the output gap on inflation in Indonesia. Similarly, Fedderke and Schaling (2005) record this effect for South Africa (using annual data from 1960 to 1999). On the other hand, Batini et al. (2005) confirm the inconclusiveness of the output gap on inflation for quarterly UK data from 1972Q3 to 1999Q2.

In a rare study making use of multiple data frequencies, Lee (1995) employs both US annual and quarterly data and conclude that the Phillips curve is unstable both across frequencies and across groups of countries.

In summary, results in this study reinforce the belief that the effects of variables are subject to frequency of data. Specifically, a variable may change from being significant to insignificant when it comes from quarterly to monthly frequency (and vice-versa). This finding implies that researchers and policymakers must be careful when making inferences about the impact of a variable as it could be influenced by data frequency.

Going into greater details, the analysis of the inflation process in Vietnam shows that significant determinants of inflation in Vietnam are the interest rates, output gap and the government budget deficit. While their significance alters between two frequencies of data, only the government budget deficit has the theoretically expected (positive) impact on inflation. Other remaining variables, namely, the interest rates (positive sign, no matter what type of interest rates used), the exchange rate (negative sign) and the output gap (negative sign, no matter how it is computed), all have unexpected effects on inflation, throwing into question the effectiveness of traditional measures of curbing inflation. The signs and significance of variables are summarized in Table 8.

\section{CONCLUSION}

Inspired by the overlooked role of data frequency in empirical macroeconomic research in general and for the Vietnamese economy in particular, this study revisited the inflation process in Vietnam using a NKPC approach from 1996M1 to 2017M3 (using both quarterly and monthly data). The main contributions of this paper include the confirmation of the role of data frequency in determining the impact of variables; the unexpected effects of interest rates (positive), exchange rate (negative) and output gap (negative) on inflation; the measurement of money supply.

Findings of this paper carry importantimplications for Vietnamese policymakers and researchers. First and foremost, the overall results lend strong support to the hypothesis that data frequency does influence the impact of independent variables in empirical research, meaning that a variable can change from being significant to insignificant when we come from one frequency to another. This implies that future studies regarding inflation in Vietnam (and also other countries) should be carried out at different frequencies before any conclusion about the effects of a variable can be made. Further, the paper also documented several interesting 


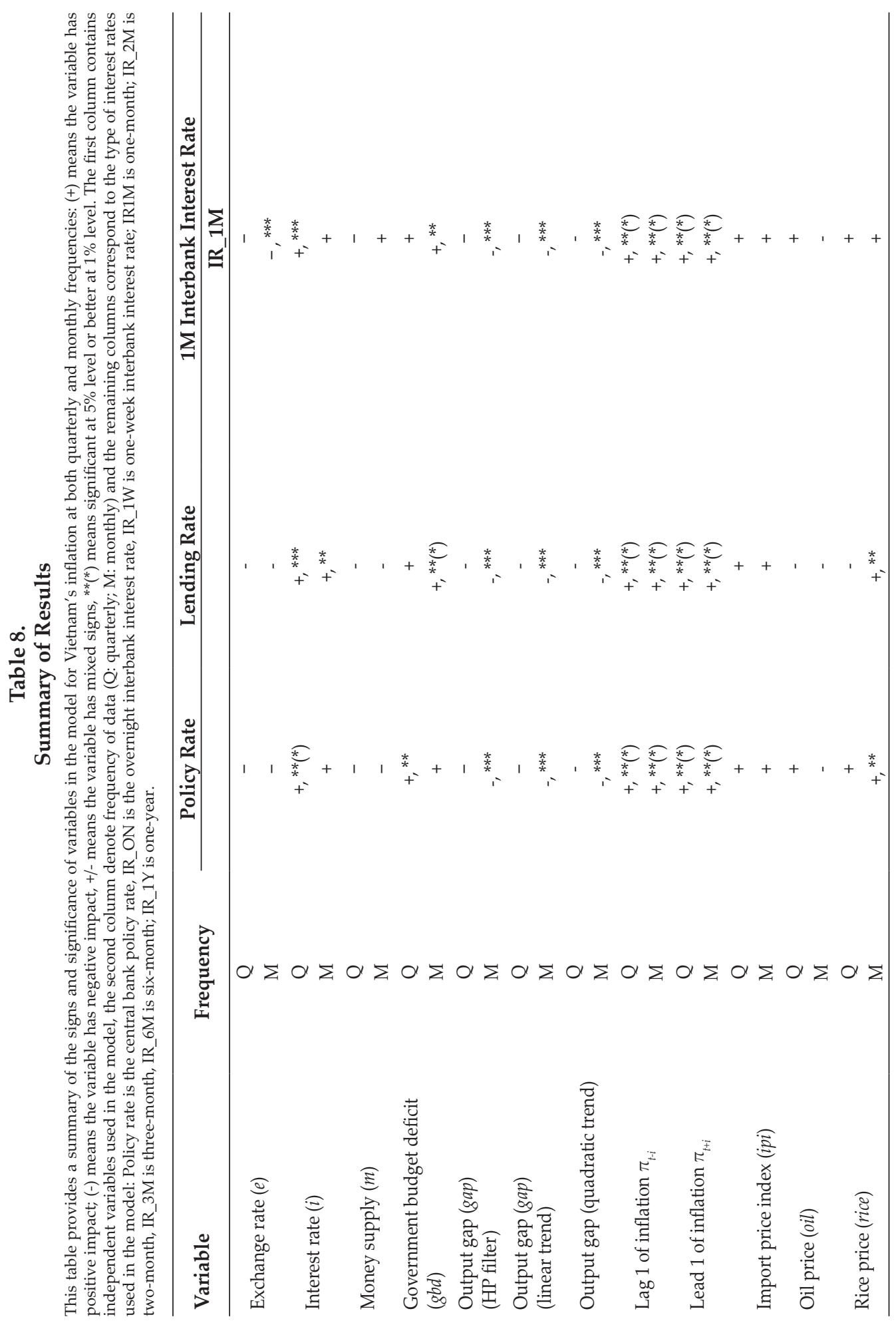


results regarding the impact of interest rates, exchange rate and output gap on inflation.

With regards to the impact of monetary policy variables on inflation, both interest rates (no matter what type of interest rate is used) and exchange rate have effects inconsistent with conventional thinking, signaling that traditional tools of containing inflation may prove counter-productive. Specifically, all types of interest rates have positive impact on inflation (although they are significant at the quarterly frequency only), meaning that higher interest rates are likely to fuel inflation rather than containing it - which goes against conventional thinking and the intended purpose of raising interest rates. This result could be attributed to several reasons such as the presence of the cost-channel of monetary policy in Vietnam, the prolonged high levels of public debt and the deeply-engrained inflation expectations in Vietnam's economic agents. Therefore, the SBV is strongly advised to implement strong measures to dampen these inflation expectations and enhance its credibility. A good choice is adopting inflation targeting - which is also a recommendation of the IMF (2017).

The exchange rate - an important monetary policy tool in Vietnam - also exerts unexpected impact on inflation. Contrary to findings of other studies, a depreciation/devaluation of the domestic currency (the Vietnam Dong) will have dampening effect on inflation and an appreciation is likely to cause inflation to hike which can be explained by the so-called wealth effect and/or uncovered interest parity. This result indicates that the effects of exchange rate on inflation are still controversial and should be investigated further.

The ratio of government budget deficit over GDP is positive across both frequencies and highly significant at the monthly level, pointing out the need for the Vietnamese government to keep its budget deficits at sustainable level as well as calling for the coordination of both monetary and fiscal policies in Vietnam (as this variable is managed by the Ministry of Finance and the Vietnamese government rather than the SBV).

The output gap, whether generated from a linear trend model or the HP filter, always exerts negative impact on inflation (inconsistent with traditional theories) which may also reflect that the current methods of computing the output gap are inappropriate and calls for further examinations of computing the output gap. Finally, the negative impact of money supply also calls into question the appropriateness of the current measurement of money supply.

\section{REFERENCES}

Abbas, S. K., Bhattacharya, P. S., \& Sgro, P. (2016). The New Keynesian Phillips Curve: An Update on Recent Empirical Advances. International Review of Economics and Finance, 43, 378-403.

Abbas, S. K., \& Sgro, P. M. (2011). New Keynesian Phillips Curve and Inflation Dynamics in Australia. Economic Modelling, 28, 2022-2033.

Adu, G., \& Marbuah, G. (2011). Determinants of Inflation in Ghana: An Empirical Investigation. South African Journal of Economics, 79, 251-269. 
Ali, S. Z., \& Anwar, S. (2013). Inflation and Interest Rates in the Presence of a Cost Channel, Wealth Effect and Agent Heterogeneity. Economic Modelling, 31, 286296.

Anwar, S., \& Nguyen, L. P. (2018). Channels of Monetary Policy Transmission in Vietnam, Journal of Policy Modeling, 40, 709-729.

Batini, N., Jackson, B., \& Nickell, S. (2005). An Open-economy New Keynesian Phillips Curve for the UK. Journal of Monetary Economics, 52, 1061-1071.

Behera, H., Wahi, G., \& Kapur, M. (2018). Phillips Curve Relationship in an Emerging Economy: Evidence from India. Economic Analysis and Policy, 59, 116-126.

Belongia, M. T., \& Ireland, P. N. (2015). A “Working” Solution to the Question of Nominal GDP Targeting. Macroeconomic Dynamics, 19, 508-534.

Belongia, M. T., \& Ireland, P. N. (2019). The Demand for Divisia Money: Theory and Evidence. Journal of Macroeconomics, 61, 103128.

Bhattacharya, R. (2014). Inflation Dynamics and Monetary Policy Transmission in Vietnam and Emerging Asia. Journal of Asian Economics, 34, 16-26.

Binner, J. M., Bissoondeeal, R. K., Elger, C. T., Jones, B. E., \& Mullineux, A. W. (2009). Admissible Monetary Aggregates for the Euro Area. Journal of International Money and Finance, 28, 99-114.

Bleaney, M., \& Francisco, M. (2018). Is the Phillips Curve Different in Poor Countries? Bulletin of Economic Research, 70, E17-E28.

Chowdhury, I., Hoffmann, M., \& Schabert, A. (2006). Inflation Dynamics and the Cost Channel of Monetary Transmission, European Economic Review, 50, 9951016.

Dahalan, J., Sharma, S. C., \& Sylwester, K. (2005). Divisia Monetary Aggregates and Money Demand for Malaysia. Journal of Asian Economics, 15, 1137-1153.

Darrat, A. F., Chopin, M. C., \& Lobo, B. J. (2005). Money and Macroeconomic Performance: Revisiting Divisia Money. Review of Financial Economics, 14, 93101.

Dhakal, D., Kandil, M., Sharma, S. C., \& Trescott, P. B. (1994). Determinants of the Inflation Rate in the United States: A VAR Investigation. The Quarterly Review of Economics and Finance, 34, 95-112.

Dizioli, A., \& Schmittmann, J. M. (2015). A Macro-model Approach to Monetary Policy Analysis and Forecasting for Vietnam. IMF Working Paper, WP/15/273.

Drake, L., \& Fleissig, A. R. (2008). A Note on the Policy Implications of Using Divisia Consumption and Monetary Aggregates. Macroeconomic Dynamics, 12, 132-149.

Elliott, J. R. (1962). The Inflationary Effects of Tight Money. Nebraska Journal of Economics and Business, 1, 43-52.

Fedderke, J., \& Schaling, E. (2005). Modelling Inflation in South Africa: A Multivariate Cointegration Analysis, South African Journal of Economics, 73, 7992.

Florackis, C., Giorgioni, G., Kostakis, A., \& Milas, C. (2014). On Stock Market Illiquidity and Real-time GDP Growth. Journal of International Money and Finance, 44, 210-229.

Florio, A. (2018). Nominal Anchors and the Price Puzzle. Journal of Macroeconomics, $58,224-237$. 
Gaiotti, E., \& Secchi, A. (2006.) Is There a Cost Channel of Monetary Policy Transmission? An Investigation into the Pricing Behavior of 2,000 Firms. Journal of Money, Credit and Banking, 38, 2013-2037.

Gali, J., \& Gertler, M. (1999). Inflation Dynamics: A Structural Econometric Analysis. Journal of Monetary Economics, 44, 195-222.

Giordani, P. (2004). An Alternative Explanation of the Price Puzzle. Journal of Monetary Economics, 51, 1271-1296.

Hahn, E. (2003). Pass-through of External Shocks to Euro Area Inflation. ECB Working Paper Series, No 243. European Central Bank.

Henzel, S., Hülsewig, O., Mayer, E. \& Wollmershäuser, T. (2009). The Price Puzzle Revisited: Can the Cost Channel Explain a Rise in Inflation After a Monetary Policy Shock? Journal of Macroeconomics, 31, 268-289.

IMF. (2017). Vietnam 2017: Article Iv Consultation. IMF Country Report No.17/190. Washington DC: International Monetary Fund.

Jalil, A., Tariq, R., \& Bibi, N. (2014). Fiscal Deficit and Inflation: New Evidences from Pakistan Using a Bounds Testing Approach. Economic Modelling, 37, 120126.

Kaufmann, S. \& Scharler, J. (2009). Financial Systems and the Cost Channel Transmission of Monetary Policy Shocks. Economic Modelling, 26, 40-46.

Kandil, M. M. E., \& Morsy, H. (2009). Determinants of Inflation in GCC. IMF Working Paper, WP/09/82.

Keen Meng, C. (2016). The Inflation Process and Expectations in Singapore. BIS Papers, No 89.

Lanne, M., \& Luoto, J. (2014) Does Output Gap, Labour's Share or Unemployment Rate Drive Inflation? Oxford Bulletin of Economics and Statistics, 76, 715-726.

Lee, J. (1995). The Phillips Curve Behavior Over Different Horizons. Journal of Economics and Finance, 19, 51-69.

Linnemann, L. (2005). Can Raising Interest Rates Increase Inflation? Economics Letters, 8, 307-311.

Mankiw, N. G. (2016). Macroeconomics. 9th Edition. Worth Publishers.

McKinnon, R. I. (1993). The Order of Economic Liberalization: Financial Control in the Transition to a Market Economy. JHU Press.

Moser, G. G. (1995). The Main Determinants of Inflation in Nigeria. IMF Staff Papers, 42, 270-289.

Narayan, P. K., Narayan, S., Rahman, R. E., \& Setiawan, I. (2019). Bitcoin Price Growth and Indonesia's Monetary System. Emerging Markets Review, 38, 364376.

Narayan, P. K., Narayan, S., \& Sharma, S. S. (2013). An Analysis of Commodity Markets: What Gain for Investors? Journal of Banking and Finance, 37, 3878-3889.

Narayan, P. K., \& Sharma, S. S. (2015). Does Data Frequency Matter for the Impact of Forward Premium on Spot Exchange Rate? International Review of Financial Analysis, 39, 45-53.

Narayan, S., \& Nguyen, T. T. (2016). Does the Trade Gravity Model depend on Trading Partners? Some Evidence from Vietnam and Her 54 Trading Partners. International Review of Economics and Finance, 41, 220-237. 
Narayan, S., \& Rehman, M. U. (2017). Diversification Opportunities Between Emerging and Frontier Asian (EFA) and Developed Stock Markets. Finance Research Letters, 23, 223-232.

Narayan, S., \& Rehman, M. U. (2019). International Portfolio Strategies and Opportunities: The Case of the US, Japan and Asia. Finance Research Letters, 101358.

Nghiem, X. H. (2020). Essays on Vietnam's Monetary Policy. Doctor of Philosophy, RMIT University.

Nguyen, T. T. H., \& Nguyen, D. T. (2010). Macroeconomic Determinants of Vietnam's Inflation 2000-2010: Evidence and Analysis. Vietnam Centre for Economic and Policy Research (VEPR) Working Paper, WP-09.

Nguyen, V. B. (2015). Effects of Fiscal Deficit and Money M2 Supply on Inflation: Evidence from Selected Economies of Asia. Journal of Economics, Finance and Administrative Science, 20, 49-53.

Nugent, J. B., \& Glezakos, C. (1982). Phillips Curves in Developing Countries: The Latin American Case. Economic Development and Cultural Change, 30, 321-334.

Oomes, N., \& Ohnsorge, F. (2005). Money Demand and Inflation in Dollarized Economies: The Case of Russia. Journal of Comparative Economics, 33, 462-483.

Paul, B. P. (2009). In Search of the Phillips Curve for India. Journal of Asian Economics, $20,479-488$.

Pelipas, I. (2006). Money Demand and Inflation in Belarus: Evidence from Cointegrated VAR, Research in International Business and Finance, 20, 200-214.

Pham, T. A. (2016). Monetary Policy and the Macroeconomic Performance of Vietnam. Doctor of Philosophy. Queensland University of Technology.

Podkaminer, L. (1998). Inflationary Effects of High Nominal Interest Rates. Journal of Post Keynesian Economics, 20, 583-596.

Rabanal, P. (2003). The Cost Channel of Monetary Policy: Further Evidence for the United States and the Euro Area. IMF Working Papers, WP/03/149.

Ramakrishnan, U., \& Vamvakidis, A. (2002) Forecasting Inflation in Indonesia. IMF Working Paper, WP/02/111.

Ratchford, B. (1973). Interest Rates and Inflation. Nebraska Journal of Economics and Business, 12, 45-54.

Ravenna, F., \& Walsh, C. E. (2006). Optimal Monetary Policy with the Cost Channel. Journal of Monetary Economics, 53, 199-216.

Rotemberg, J. J., Driscoll, J. C., \& Poterba, J. M. (1995). Money, Output, and Prices: Evidence from a New Monetary Aggregate. Journal of Business and Economic Statistics, 13, 67-83.

Rother, P. C. (2000). Inflation in Albania. IMF Working Paper, WP/00/207.

Schunk, D. L. (2001). The Relative Forecasting Performance of the Divisia and Simple Sum Monetary Aggregates. Journal of Money, Credit and Banking, 33, 272-283.

Serletis, A., \& Rahman, S. (2013). The Case for Divisia Money Targeting. Macroeconomic Dynamics, 17, 1638-1658.

Su, C, W., Fan, J, J., Chiang, H, L., \& Li, X, L. (2016). Is There Causal Relationship Between Money Supply Growth and Inflation in China? Evidence from Quantity Theory of Money Review of Development Economics, 20, 702-719. 
Tillmann, P. (2009). The Time-varying Cost Channel of Monetary Transmission. Journal of International Money and Finance, 28, 941-953.

Tran, N. (2018). The Long-run Analysis of Monetary Policy Transmission Channels on Inflation: A VECM Approach. Journal of the Asia Pacific Economy, 23, 17-30.

Vo, X. V., \& Nguyen, P. C. (2017) Monetary Policy Transmission in Vietnam: Evidence from a VAR Approach. Australian Economic Papers, 56, 27-38.

Wimanda, R. E., Turner, P. M., \& Hall, M. J. (2011). Expectations and the Inertia of Inflation: The Case of Indonesia. Journal of Policy Modeling, 33, 426-438. 
This page is intentionally left blank 